\title{
Pregnancy and Covid-19: A Literature Review
}

\author{
Chahya Kharin Herbawani*, Salshabiyla Naura Almamira Cukarso, Intan Muzdhalifa \\ Maulana, Flavia Stefanie Ananda Utami \\ Faculty of Health, UPN Veteran Jakarta, Indonesia \\ *Corresponding author. Email: chahyakharin@upnvj.ac.id
}

\begin{abstract}
Background: Coronavirus is a large family of viruses that can cause disease from mild to severe symptoms. COVID-19 attacks people of all ages including vulnerable groups such as pregnant women. Numbers of previous researches on the coronavirus, (SARS-CoV and MERS-CoV), stated that pregnant women have a higher risk of severe disease, morbidity, and mortality compared to the general population. However, there are only a few studies on COVID-19's relationship with pregnancy and childbirth. Methods: This research used a literature review method. Sources of literature data were obtained from PubMed, Ebsco and Proquest taken from 2019-2020. Results: The results of the research based on 7 articles. The results showed that there was no difference in the signs and symptoms experienced by pregnant women with Covid-19 infection when compared to the general population. Until today, a number of studies have been conducted to determine the vertical transmission of COVID-19 from mother to fetus. Conclusions: A number of samples such as umbilical cord blood, amniotic fluid, neonatal throat swab, breast milk, and vaginal secretions were taken for examination and showed negative results. Maternal-fetal transmission of COVID-19 was undetected in the majority of reported cases. Yet, careful pregnancy monitoring with COVID-19 and steps to prevent neonatal infection is still needed. Mothers who are infected are at a higher risk of having severe respiratory complications.
\end{abstract}

Keywords: COVID-19, Pregnancy, Maternal Health

\section{INTRODUCTION}

COVID-19 becomes serious attention in public health after being recognized as a pandemic. The first case of COVID-19 was reported in Wuhan in 2019. For the first time, WHO addressed this disease as the Novel Coronavirus 2019 or 2019-nCoV[1]. Furthermore, on February 11, 2020, the WHO officially announced COVID-19 as a disease caused by Severe Acute Respiratory Syndrome Coronavirus-2 (SARS-CoV-2).. The virus infects and damages the tissue in the human airway [2]. Based on data compiled from the WHO website, up to July 24, 2020, there were 15,257,287 confirmed cases reported and caused 628,240 deaths due to COVID-19 in the world [3]. Meanwhile in Indonesia, on July 24, 2020, there were 95,418 confirmed positive cases and 4,665 deaths due to COVID-19 [4]. This number keeps increasing until today.

COVID-19 attacks people of all ages including vulnerable groups, such as pregnant women. In the condition of pregnancy, there are physiological changes in the body and maternal immunity that cause an increase in susceptibility to infection and disease [5]. A study conducted by Elshafeey, et al, of 385 pregnant women infected with COVID-19, 346 of whom were confirmed positive from the results of the RT-PCR examination. The $7.5 \%$ of pregnant women infected with COVID-19 did not show symptoms related to COVID-19 [6]. The immune response of each individual determines the severity of cell damage due to viral infection [2].

Covid-19 transmission can occur from human to human[7]. However, in the case of pregnancy, a number of researchers are still conducted to determine the transmission of COVID-19 from mother to fetus [8]. Several studies have revealed cases of pregnancy complications that have occurred in mothers infected with COVID-19. Pneumonia that occurs during pregnancy is associated with several obstetric disorders, such as premature rupture of membranes, fetal death in utero, intrauterine growth disorders, and neonatal death [9]. Chen, et al's research on nine pregnant women infected with COVID-19 in the 3rd trimester, four of them gave birth prematurely at 36 weeks of pregnancy, and two babies were born with LBW. In addition, there were two other cases where fetal distress and premature rupture of membranes were experienced [10].

Another research conducted by Elshafeey, et al, stated that 368 pregnant women were classified as mild cases, 14 had severe cases and 3 others were critical cases. At the time of delivery, 20 cases of fetal distress and low birth weight were reported, respectively. The research also stated that out of 256 births, there were two cases of 
infant mortality and four babies tested positive based on the results of the PCR test[6].

A number of previous researches on the coronavirus (SARS-CoV and MERS-CoV) stated that pregnant women have a higher risk of severe disease, morbidity, and mortality when compared to the general population [11]. However, there are only a few studies on COVID19 's relation to pregnancy and childbirth. Therefore, this research aims to determine the risks and impacts of COVID-19 on pregnancy and childbirth.

\section{METHODS}

This research used a litterature review. The author uses PRISMA guidelines for systematic reviews. This literature data source is obtained from PubMed, EBSCO and Proquest. This research data are taken from the years 2019-2020. The journal inclusion criteria used are journals that could be accessed completely, using Indonesian and or English, and report cases due to COVID-19 related to pregnancy and childbirth. Meanwhile, the exclusion criteria consist of journals that have been drawn by the author and duplicated journals.

\section{RESULTS}

The author identifies 5 articles based on the inclusion criteria of the research. Most of the journals use to report cases of pregnancy with COVID-19 in China. However, there are other journals reporting cases in America, Iran, the UK, and France.
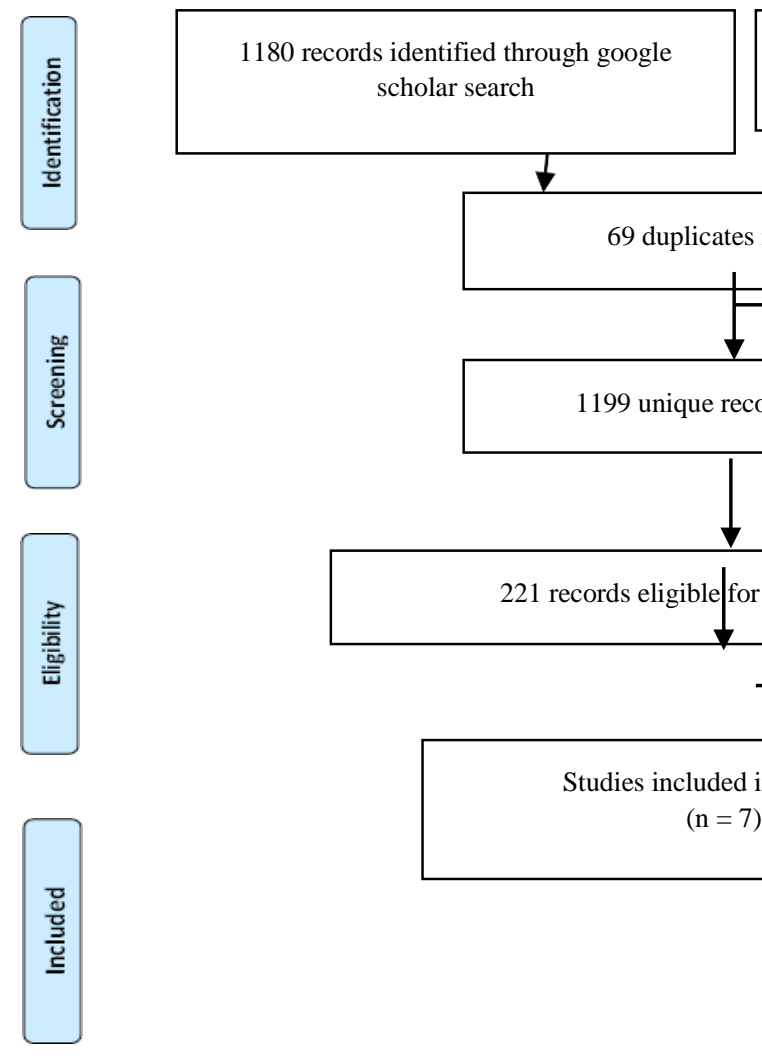

88 records identified through PUBMED search

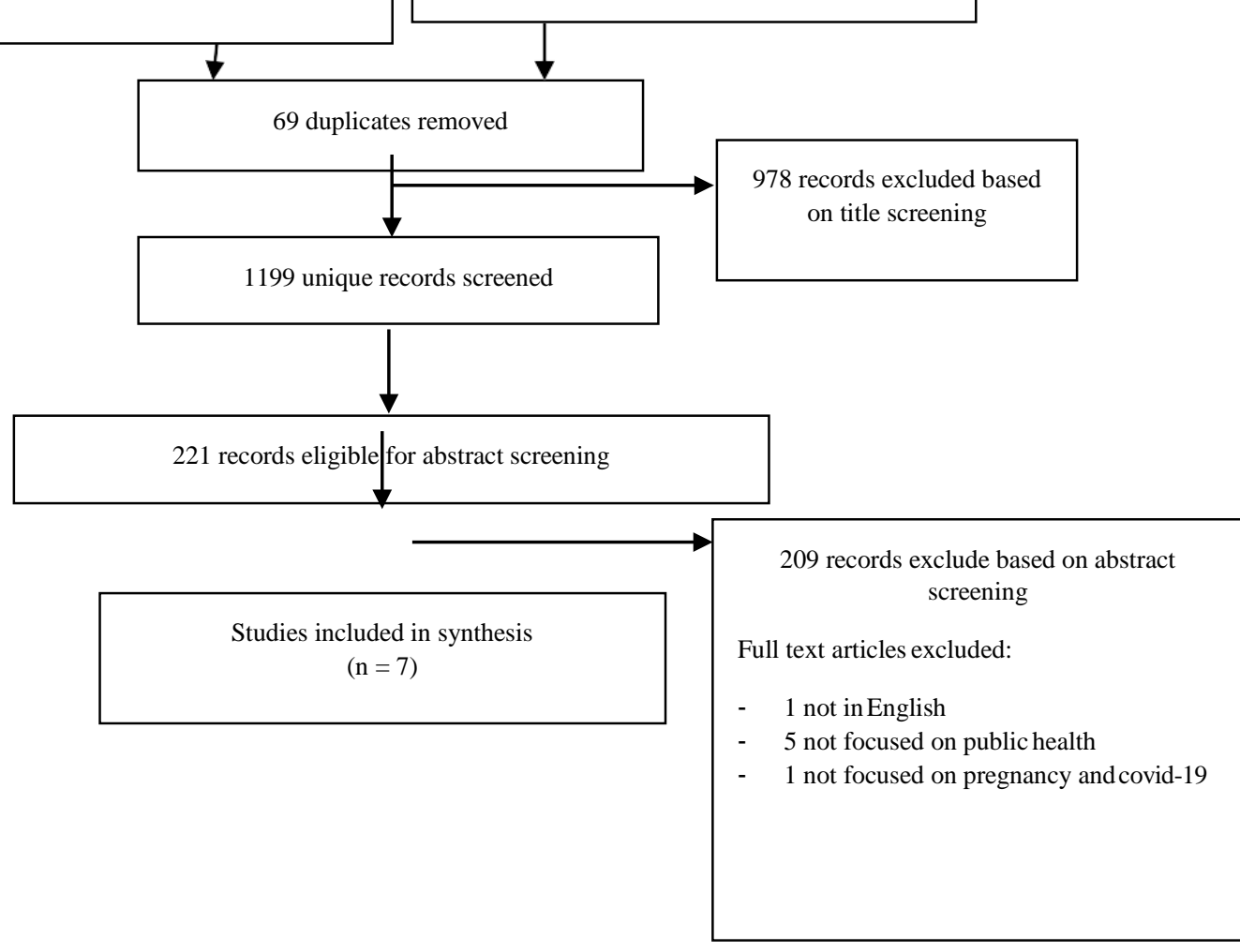

Figure 1 PRISMA Flow Diagram 
Table 1.

Risks of Covid-19 in Pregnancy

\begin{tabular}{|c|c|c|c|c|}
\hline Authors & Location & Design Study & $\begin{array}{c}\text { Sample study } \\
\text { with } \\
\text { confirmed } \\
\text { case }\end{array}$ & Key Findings \\
\hline $\begin{array}{c}\text { Chen et al., } \\
2020\end{array}$ & China & $\begin{array}{c}\text { Retrospective } \\
\text { Review }\end{array}$ & $\begin{array}{l}9 \text { pregnant } \\
\text { women }\end{array}$ & $\begin{array}{l}\text { 1. The most common symptoms } \\
\text { felt by pregnant women are } \\
\text { fever, cough, myalgia, sore } \\
\text { throat, and malaise. These } \\
\text { clinical symptoms also occur } \\
\text { in common patients infected } \\
\text { with COVID-19. } \\
\text { 2. There are two cases of fetal } \\
\text { distress. } \\
\text { 3. In nine babies born, no cases } \\
\text { of neonatal asphyxia were } \\
\text { reported. } \\
\text { 4. This research states that there } \\
\text { is no evidence of intrauterine } \\
\text { infection due to vertical } \\
\text { transmission occurring in } \\
\text { pregnant women. }\end{array}$ \\
\hline Liu et al., 2020 & China & Case Series & $\begin{array}{c}15 \text { pregnant } \\
\text { women }\end{array}$ & $\begin{array}{l}\text { 1. The general symptoms of } \\
\text { COVID-19 are fever and } \\
\text { cough. } \\
\text { 2. At the end of the research, } 11 \\
\text { out of } 15 \text { samples have been } \\
\text { delivered and there are no } \\
\text { reports of cases of COVID-19 } \\
\text { infection in babies born, } \\
\text { neonatal asphyxia, neonatal } \\
\text { deaths, stillbirths, or } \\
\text { abortions. }\end{array}$ \\
\hline $\begin{array}{l}\text { London et al., } \\
\qquad 2020\end{array}$ & Amerika & $\begin{array}{c}\text { Kohort } \\
\text { Retrospektif }\end{array}$ & $\begin{array}{c}68 \text { pregnant } \\
\text { women }\end{array}$ & $\begin{array}{l}\text { 1. } 27.3 \% \text { of women who had } \\
\text { COVID-19 symptoms gave } \\
\text { birth prematurely and } 26.1 \% \\
\text { needed assistance with } \\
\text { breathing } \\
\text { 2. Pregnant women who showed } \\
\text { symptoms of COVID-19 have } \\
\text { a higher rate of preterm labor } \\
\text { and respiratory assistance } \\
\text { than pregnant women without } \\
\text { symptoms of COVID-19. }\end{array}$ \\
\hline
\end{tabular}


Table 2.

Risks of Covid-19 in Pregnancy (Lanjutan)

\begin{tabular}{|c|c|c|c|c|}
\hline Authors & Location & $\begin{array}{l}\text { Design } \\
\text { Study }\end{array}$ & $\begin{array}{c}\text { Sample study } \\
\text { with confirmed } \\
\text { case }\end{array}$ & Key Findings \\
\hline \multirow[t]{2}{*}{$\begin{array}{r}\text { Hantoushzadeh } \\
\text { et al., } 2020\end{array}$} & Iran & Case Series & $\begin{array}{r}7 \text { pregnant } \\
\text { women }\end{array}$ & $\begin{array}{l}\text { 1. There are } 7 \text { cases of death of pregnant } \\
\text { women infected with COVID-19 in } \\
\text { the severe category. }\end{array}$ \\
\hline & & & & $\begin{array}{l}\text { 2. This research collected data on a } \\
\text { family cohort showing that pregnant } \\
\text { women have more severe symptoms } \\
\text { than other family members. }\end{array}$ \\
\hline \multirow[t]{3}{*}{$\begin{array}{r}\text { Antoun et al., } \\
2020\end{array}$} & Inggris & $\begin{array}{r}\text { Kohort } \\
\text { Prospektif }\end{array}$ & $\begin{array}{l}23 \text { pregnant } \\
\text { women }\end{array}$ & $\begin{array}{l}\text { 1. Of } 23 \text { pregnant women, } 4 \text { cases } \\
\text { experienced severe respiratory } \\
\text { problems and resulted in } 1 \text { case of } \\
\text { death of pregnant women. }\end{array}$ \\
\hline & & & & $\begin{array}{l}\text { 2. There are } 7 \text { cases of preterm birth and } \\
2 \text { cases of pre-eclampsia. }\end{array}$ \\
\hline & & & & $\begin{array}{l}\text { 3. COVID-19 is closely related to the } \\
\text { incidence of preterm birth, pre- } \\
\text { eclampsia, and cesarean delivery } \\
\text { compared to pregnancies without } \\
\text { COVID-19 cases. }\end{array}$ \\
\hline \multirow[t]{3}{*}{$\begin{array}{c}\text { Chen and Bai, } \\
2020\end{array}$} & China & Case Series & $\begin{array}{l}21 \text { pregnant } \\
\text { women }\end{array}$ & $\begin{array}{l}\text { 1. All pregnant women who have mild } \\
\text { and moderate symptoms can be cured } \\
\text { and deliver successfully. }\end{array}$ \\
\hline & & & & $\begin{array}{l}\text { 2. The clinical symptoms that arise in } \\
\text { pregnant women with COVID-19are } \\
\text { milder than in non-pregnant patients } \\
\text { infected with COVID-19. }\end{array}$ \\
\hline & & & & $\begin{array}{l}\text { 3. There is no evidence of vertical } \\
\text { transmission from mother to baby. }\end{array}$ \\
\hline \multirow{4}{*}{$\begin{array}{l}\text { Sentilhes } \text { et al., } \\
2020\end{array}$} & Prancis & Single-centre & 38 pregnant & 1. There is one case of miscarriage. \\
\hline & & st & $\mathrm{W}$ & $\begin{array}{l}\text { 2. Five of the } 21 \text { women delivered } \\
\text { prematurely, } 3 \text { cases delivered before } \\
32 \text { weeks gestation, and } 2 \text { cases } \\
\text { delivered before } 28 \text { weeks gestation. }\end{array}$ \\
\hline & & & & $\begin{array}{l}\text { 3. COVID-19 is associated with } \\
\text { maternal morbidity and preterm } \\
\text { delivery. }\end{array}$ \\
\hline & & & & $\begin{array}{l}\text { 3. The rate of post-partum bleeding and } \\
\text { blood transfusions of pregnant } \\
\text { women with COVID-19 is higher } \\
\text { than the general population of } \\
\text { pregnant women. }\end{array}$ \\
\hline
\end{tabular}


Pregnancy Complications and Death. There are 8 cases of maternal death[16],[15], [19]. In addition, in a study conducted by London et al., It is reported that there is one case of fetal death at 17 weeks gestation[14]. From 23 pregnant women, 4 cases experienced severe respiratory problems. There are pregnancy complications that arise in women with COVID-19, such as fetal distress and premature rupture of membranes[19].

Signs and Symptoms of COVID-19 on Pregnant Women. Based on symptoms and signs reported, Most of the pregnant women infected with COVID-19 experience fever $(\mathrm{n}=171,47.10 \%)$, cough $(\mathrm{n}=164$, $45.17 \%)$, feeling tired $(n=69,35.5 \%)$, sore throat $(n=$ $29,16.29 \%)$ ), myalgia $(\mathrm{n}=30,15.07 \%)$, and dyspnea ( $\mathrm{n}$ $=16,8.04 \%)$. Besides, there are other symptoms and signs that pregnant women feel, such as diarrhea, malaise, and chest pain. A total of 67 pregnant women out of 363 did not show symptoms related to COVID-19. The signs and symptoms experienced by pregnant women are no different when compared to the general population infected with COVID-19[20].

\section{Delivery of Pregnant Women Infected with COVID-}

19. Most of pregnant women with COVID-19 gave birth by cesarean section. There are many cases of premature babies born to mothers infected with COVID-19. Most researchers stated babies born to mothers infected with COVID-19 are reported negative for COVID-19 after an RT-PCR test. Samples are taken in the form of amniotic fluid, neonatal throat swab, umbilical cord blood, and breast milk[19]. However, there is one case report of a baby confirmed positive for COVID-19 within 36 hours of birth[20]. After testing positive based on the results of the neonatal throat swab test, the baby was referred to the children's hospital for further treatment. All research state that babies born has a normal APGAR score. Before delivery, some of pregnant women were given oxygen support and empiric antibiotics as well as antiviral therapy after delivery[13].

\section{DISCUSSIONS}

Pregnant women are a vulnerable group to pathogens that cause respiratory diseases and pneumonia. This can occur because, during pregnancy, pregnant women are in an immunosuppressive state and experience physiological changes in pregnancy, such as an increase in the diaphragm, increased oxygen consumption, and edema of the respiratory tract which can make it susceptible to hypoxia. In addition, the decreased immunity of pregnant women can lead to increased susceptibility to infectious diseases. In cases caused by the SARS virus, $50 \%$ of pregnant women undergo intensive care in the ICU, 33\% need ventilator assistance, and $25 \%$ of pregnant women die from the SARS virus. Besides, during the H1N1 virus pandemic, pregnant women are reported to have a higher risk of complications from $\mathrm{H} 1 \mathrm{~N} 1$ virus infection and four times the risk of undergoing intensive care in hospitals compared to the general population[13]. Several studies have stated that pregnant women with COVID-19 show signs and symptoms similar to those of adults with COVID-19 in general[21].

Yet, some cases can show different signs and symptoms, even if they don't show any. Laboratory test results also convey that lymphopenia can occur and an increase in ALT and ALS levels are as a clinical manifestation of COVID-19. Symptomatic pregnant women have higher lymphopenia rates than pregnant women without COVID-19 symptoms ( $\mathrm{n}^{1 / 416}, 66.7 \%$ vs. $\mathrm{n}^{1 / 48}, 36.4 \%, \mathrm{p}$ $1 / 4$ 0.022)[14]. Normal or cesarean delivery is not a result of COVID-19 infection in the mother. Premature labor that occurs in mothers/women infected with COVID-19 can be caused by stress or psychological stress during pregnancy due to the mother being infected with COVID-19[22]. Cesarean delivery also can't be related due to the mother being infected with COVID-19. There are several indications of pregnancy that lead to having to undergo cesarean delivery, such as severe preeclampsia, a history of cesarean section, and cases of fetal distress. In addition, preterm labor can also be caused by complications of pregnancy such as preeclampsia or other causes[19]. Research conducted by London et al stated that of the nine cases of preterm labor, eight of them are iatrogenic (seven cases of respiratory distress and one case due to decreased fetal movement)[14].

Although several studies have reported cases of pregnant women infected with COVID-19 in the final trimester of pregnancy until now there is still no evidence that COVID-19 can cause a severe impact due to intrauterine vertical transmission[12]. Research conducted by Chen, et al took samples from the amniotic fluid of a COVID19 sufferer during childbirth. In addition, samples of umbilical cord blood, neonatal throat swabs, and breast milk are also collected for examination. The samples are examined in a laboratory of the School of Basic Medical Sciences at Wuhan University. The result is that all samples tested negative for COVID-19[19]. The research conducted by Yan, et al, took samples of vaginal secretions and the results shown are also negative for COVID-19[10].

\section{CONCLUSION}

Group of pregnant women becomes a vulnerable group of COVID-19. This is because, during pregnancy, the 
body is in an immunosuppressive state and undergoes physiological changes in pregnancy, such as an increase in the diaphragm, increased oxygen consumption, and edema of the respiratory tract that can make it susceptible to hypoxia. Symptoms and signs arising from COVID19 infection can be different in each individual. Symptoms that arise in pregnant women do not have a significant difference compared to the symptoms that occur in the general population with COVID-19 infection. Until today, a number of studies have been conducted to determine the vertical transmission of COVID-19 from mother to fetus. A number of samples such as umbilical cord blood, amniotic fluid, neonatal throat swab, breast milk, and vaginal secretions are taken for examination and showed negative results. The cases of complications and deaths occurred are not related to COVID-19 infection. It is expected that there are further researchers regarding vertical transmission Pregnant women with COVID-19 cases are expected to undergo intensive care to minimize the impact that may arise due to COVID-19 infection.

\section{REFERENCES}

[1] A. A. Pradana, Casman, and Nur'aini, "Pengaruh Kebijakan Social Distancing Pada Wabah Covid-19 Terhadap Kelompok Rentan di Indonesia," J. Kebijak. Kesehat. Indones., vol. 9, no. 2, pp. 61-67, 2020.

[2] J. T. Atmojo, P. S. Akbar, and S. Kuntari, "Definisi dan Jalur Penularan Severe Acute Respiratory Syndrome Coronavirus 2 ( SARS-Cov-2 )," J. Pendidik. Kesehat., vol. 9, no. 1, pp. 57-64, 2020.

[3] WHO, "Brazil: WHO Coronavirus Disease (COVID-19) Dashboard I WHO Coronavirus Disease (COVID19) Dashboard,"Who. 2020.

[4] Gugus Tugas Percepatan Penanganan COVID, "Informasi terbaru seputar penanganan COVID-19 di Indonesia," 2020 . .

[5] M. Zaigham and O. Andersson, "Maternal and perinatal outcomes with COVID-19: A systematic review of 108 pregnancies," pp. 1-7, 2020.
[6] F. Elshafeey, R. Magdi, N. Hindi, M. Elshebiny, M. Nasser, M. Kamel, A. Amir, and M. Maher, "A systematic Scoping Review of COVID-19 During Pregnancy and Childbirth," no. May, pp. 47-52, 2020.

[7] WHO, "Coronavirus Disease Situation Report World Health Organization," World Heal. Organ., vol. 19, no. May, pp. 1-17, 2020.

[8] Perkumpulan Obstetri dan Ginekologi Indonesia, "Rekomendasi Penanganan Infeksi Virus Corona (Covid-19) Pada Maternal (Hamil, Bersalin Dan Nifas)," Penanganan Infeksi Virus Corona Pada Matern., vol. 1, no. 3, pp. 9-11, 2020.

[9] D. A. Schwartz and A. L. Graham, "Potential Maternal and Infant Outcomes from Coronavirus 2019nCoV (SARS-CoV-2) Infecting Pregnant Women: Lessons from SARS, MERS, and Other Human Coronavirus Infections," Viruses, vol. 12, no. 194, pp. 1-16, 2020.

[10] J. Yan, J. Guo, C. Fan, J. Juan, X. Yu, J. Li, L. Feng, C. Li, H. Chen, Y. Qiao, D. Lei, C. Wang, G. Xiong, F. Xiao, W. He, Q. Pang, X. Hu, S. Wang, D. Chen, Y. Zhang, L. C. Poon, and H. Yang, "Coronavirus disease 2019 in pregnant women: a report based on 116 cases," Am. J. Obstet. Gynecol., vol. 223, no. 1, p. 111.e1-111.e14, 2020.

[11] M. Karimi-Zarchi, H. Neamatzadeh, and S. Alireza, "Vertical Transmission of Coronavirus Disease 19 ( COVID-19 ) from Infected Pregnant Mothers to Neonates : A Review," Fetal Pediatr. Pathol., vol. 0, no. 0, pp. 1-5, 2020.

[12] H. Chen, J. Guo, C. Wang, F. Luo, X. Yu, W. Zhang, J. Li, D. Zhao, D. Xu, Q. Gong, J. Liao, and H. Yang, "Clinical characteristics and intrauterine vertical transmission 
potential of COVID-19 infection in nine pregnant women : a retrospective review of medical records," Lancet, vol. 395, no. 10226, pp. 809-815, 2020.

[13] D. Liu, L. Li, D. Zheng, J. Wang, L. Yang, and C. Zheng, "Pregnancy and Perinatal Outcomes of Women With Coronavirus Disease (COVID-19) Pneumonia: A Preliminary Analysis," Am. J. Roentgenol., vol. 215, no. July, pp. 1-6, 2020.

[14] V. London, R. M. Jr, F. Atallah, C. Cepeda, S. Mccalla, N. Fisher, J. L. Stein, M. S. S. Haberman, and H. Minkoff, "The Relationship between Status at Presentation and Outcomes among Pregnant Women with COVID19," Am. J. Perinatol., vol. 37, no. 10, pp. 991-994, 2020.

[15] S. Hantoushzadeh, A. A. Shamshirsaz, A. Aleyasin, M. D. Seferovic, S. K. Aski, S. E. Arian, P. Pooransari, F. Ghotbizadeh, S. Aalipour, Z. Soleimani, M. Naemi, B. Molaei, R. Ahangari, M. Salehi, A. D. Oskoei, P. Pirozan, R. F. Darkhaneh, M. G. Laki, A. K. Farani, S. Atrak, M. M. Miri, M. Kouchek, S. Shojaei, F. Hadavand, F. Keikha, M. S. Hosseini, S. Borna, S. Ariana, M. Shariat, A. Fatemi, B. Nouri, S. M. Nekooghadam, and K. Aagaard, "Maternal death due to COVID-19," Am. J. Obstet. Gynecol., vol. 223, no. 1, p. 109.e1-109.e16, 2020 .

[16] L. Antoun, N. El Taweel, I. Ahmed, S. Patni, and H. Honest, "Maternal COVID-19 infection, clinical characteristics, pregnancy, and neonatal outcome: A prospective cohort study," Eur. J. Obstet. Gynecol., no. 2019, pp. 8-11, 2020.

[17] Y. Chen and J. Bai, "Maternal and infant outcomes of full-term pregnancy combined with COVID-2019 in

Wuhan, China: retrospective case series," Arch. Gynecol. Obstet., pp. 17, Jul. 2020.

[18] L. Sentilhes, F. De Marcillac, C. Jouffrieau, P. Kuhn, V. Thuet, Y. Hansmann, Y. Ruch, and P. Deruelle, "Coronavirus disease 2019 in pregnancy was associated with maternal morbidity and preterm birth," Am. J. Obstet. Gynecol. MFM, pp. 115, 2020.

[19] Y. Chen, H. Peng, L. Wang, Y. Zhao, L. Zeng, H. Gao, and Y. Liu, "Infants Born to Mothers With a New Coronavirus (COVID-19)," Front. Pediatr., vol. 8, no. 104, pp. 1-5, 2020.

[20] N. Yu, W. Li, Q. Kang, Z. Xiong, S. Wang, X. Lin, Y. Liu, J. Xiao, H. Liu, D. Deng, and S. Chen, "Clinical features and obstetric and neonatal outcomes of pregnant patients with COVID-19 in Wuhan, China: a retrospective, single-centre, descriptive study," Lancet Infect. Dis., vol. 20, no. 5, pp. 559-564, 2020.

[21] C. Huang, Y. Wang, X. Li, L. Ren, J. Zhao, Y. Hu, L. Zhang, G. Fan, J. Xu, X. Gu, Z. Cheng, T. Yu, J. Xia, Y. Wei, W. Wu, X. Xie, W. Yin, H. Li, M. Liu, Y. Xiao, H. Gao, L. Guo, J. Xie, G. Wang, R. Jiang, Z. Gao, Q. Jin, J.

Wang, and B. Cao, "Clinical features of patients infected with 2019 novel coronavirus in Wuhan, China," Lancet, vol. 395, no. 10223, pp. 497-506, 2020.

[22] S. Khan, L. Peng, R. Siddique, G. Nabi, Nawsherwan, M. Xue, J. Liu, and G. Han, "Impact of COVID-19 infection on pregnancy outcomes and the risk of maternal-to-neonatal intrapartum transmission of COVID-19 during natural birth," Infect. Control Hosp.Epidemiol., vol. 41, no. 6, pp. 748-750, Jun. 2020. 